\title{
CLB5: a novel B cyclin from budding yeast with a role in $S$ phase
}

\author{
Charles B. Epstein and Frederick R. Cross \\ The Rockefeller University, New York, New York 10021 USA
}

\begin{abstract}
Budding yeast strains have three $C L N$ genes, which have limited cyclin homology. At least one of the three is required for cell cycle START. Four B cyclins are known in yeast; two have been shown to function in mitosis. We have discovered a fifth B-cyclin gene, called CLB5, which when cloned on a CEN plasmid can rescue strains deleted for all three $C L N$ genes. $C L B 5$ transcript abundance peaks in $\mathrm{G}_{1}$, coincident with the $C L N 2$ transcript but earlier than the CLB2 transcript. CLB5 deletion does not cause lethality, either alone or in combination with other $C L N$ or $C L B$ deletions. However, strains deleted for $C L B 5$ require more time to complete S phase, suggesting that $C L B 5$ promotes some step in DNA synthesis. CLB5 is the only yeast cyclin whose deletion lengthens $\mathrm{S}$ phase. $C L B 5$ may also have some role in promoting the $\mathrm{G}_{1} / \mathrm{S}$ transition, because $c \ln 1 \operatorname{cln} 2$ strains require both $C L N 3$ and $C L B 5$ for viability on glycerol media and $c \ln 1,2,3^{-}$strains require CLB5 for rescue by the Drosophila melanogaster $c d c 2$ gene. In conjunction with $c \ln 1,2,3^{-}$rescue by $C L B 5$ overexpression and the coincident transcriptional regulation of $C L B 5$ and $C L N 2$, these observations are suggestive of partial functional redundancy between $C L B 5$ and $C L N$ genes.
\end{abstract}

[Key Words: Cyclin; CLB5; S phase; Saccharomyces cerevisiae; cell cycle control]

Received May 14, 1992; revised version accepted June 26, 1992.

Progression through the eukaryotic cell cycle is controlled by the protein kinase $c d c 2 / C D C 28$. In budding yeast and fission yeast, this kinase is required for cell cycle START [commitment to cell cycle progression late in $\mathrm{G}_{1}$ (Pringle and Hartwell 1981)], for mitosis (Hartwell 1991), and for meiosis (Niwa and Yanagida 1988; Shuster and Byers 1989). In higher eukaryotic cells, the involvement of this kinase in mitosis (Hartwell 1991) and meiosis (Labbe et al. 1988) is established. There are also indications that either $c d c 2$ or a related protein kinase may have a role early in the cell cycle (Blow and Nurse 1990; D'Urso et al. 1990; Pines and Hunter 1990a; Fang and Newport 1991).

$c d c 2 / C D C 28$ functions only when activated by binding to members of a class of proteins called cyclins. Cyclins of the B-type sequence class are generally associated with activation of $c d c 2 / C D C 28$ in mitosis. Four B-type cyclin genes have been reported in Saccharomyces cerevisiae $(C L B 1, C L B 2, C L B 3$, and $C L B 4$; Ghiara et al. 1991; Surana et al. 1991).CLB1, CLB2, and CLB4 were discovered as high-copy suppressors of a conditional allele of $c d c 28$ having $\mathrm{a}_{2} / \mathrm{M}$ terminal phenotype (Surana et al. 1991). CLB1 mutations promoting the stability of the protein lead to M-phase arrest (Ghiara et al. 1991), whereas deletion of CLB2 leads to delayed entry into $M$ phase (Surana et al. 1991). Simultaneous deletion of $C L B 2$ and either CLB1 or CLB3 arrests cells in $\mathrm{G}_{2}$ on the basis of tetrad analysis (Surana et al. 1991; D. Lew and S. Reed, pers. comm.). In contrast, the Schizosaccharomyces pombe cig $1^{+}$gene is a B cyclin that is required for efficient passage of the $G_{1} / S$ transition (Bueno et al. 1991 .

A-type cyclins may also activate $c d c 2$ in mitosis; however, growing evidence suggests a role for A-type cyclins complexed with Cdc2 or the Cdc2-related kinase Cdk2 earlier in the cell cycle, particularly at DNA replication (Pines and Hunter 1990b; Girard et al. 1991; Tsai et al. 1991). In higher eukaryotes, it is not clear whether cyclin $\mathrm{A} /$ kinase complexes are required for $\mathrm{S}$ phase throughout its duration or only at the $G_{1} / S$ transition. In budding yeast, no cyclin-A homologs are known nor is there any genetic evidence that $C D C 28$ is involved directly in $S$-phase progression.

In S. cerevisiae, START is dependent on the distant cyclin homologs CLN1,CLN2, and CLN3 (Richardson et al. 1989), as well as on CDC28. The products of the $C L N$ genes bind to (Wittenberg et al. 1990; F. Cross and C. Blake, unpubl.) and activate (R. Deshaies, pers. comm.) the $C D C 28$ protein kinase. The three $C L N$ genes are functionally redundant; any one of the three is sufficient for viability (Richardson et al. 1989). Triple CLN deficiency causes $G_{1}$ arrest, before START (Cross 1990). The genes for human cyclins C, D, and E (Koff et al. 1991; Lew et al. 1991; Matsushime et al. 1991; Xiong et al. 1991) and Drosophila melanogaster cyclin C (Lahue et al. 1991; Leopold and O'Farrell 1991) were isolated on the basis of their ability to rescue $\operatorname{cln} 1,2,3^{-}$yeast strains. The normal roles of these cyclins are still unclear. Human cyclin $\mathrm{A}$ and cyclins $\mathrm{B} 1$ and $\mathrm{B} 2$, as well as $S$. pombe $c d c 13^{+}$, a mitotic B-type cyclin, also functioned in the 
$\operatorname{cln} 1,2,3^{-}$rescue assay (Koff et al. 1991; Lew et al. 1991; Xiong et al. 1991). These rescue experiments all employed a strong yeast promoter and high-copy plasmids, presumably promoting gross overexpression of the foreign cyclin.

Here, we report the discovery of a fifth yeast B cyclin that is capable of rescuing $\operatorname{cln} 1,2,3^{-}$lethality when present on a low-copy-number plasmid under the control of its own promoter. Deletion of this gene (CLB5) results in a marked slowing of $S$-phase progression, rather than a delay in the $G_{1} / S$ or $G_{2} / M$ transitions. CLB5 RNA is expressed early in the cell cycle, in contrast to other B-type cyclins (Ghiara et al. 1991; Surana et al. 1991). These observations suggest that CLB5 is a B-type cyclin functioning early in the cell cycle and is required for efficient DNA replication.

\section{Results}

Isolation of a novel $B$ cyclin rescuing the cln $1,2,3^{-}$genotype

Yeast strains deleted for all three CLN genes are inviable but can be maintained if supplied with a plasmid copy of a CLN gene. We constructed a library in a CEN (lowcopy) plasmid, using genomic DNA from a haploid yeast strain (relevant genotype: $\operatorname{cln} 1 C L N 2 \operatorname{cln} 3$ ). The library was screened for plasmids that could rescue a strain with the genotype $\ln 1 \operatorname{cln} 2 \operatorname{cln} 3$ [pGAL1::CLN3/URA3], under conditions (i.e., glucose media) where GAL1::CLN3 was not being synthesized. We recovered eight distinct clones of CLN2 and three distinct clones of a novel gene. Subcloning experiments identified the minimal region of these plasmids required for $\ln 1,2,3^{-}$rescue (Fig. 1). This region was sequenced in its entirety (Fig. 2) and was found to contain a single open reading frame of 435 amino acids. The translated sequence was aligned by use of the FASTA homology search program (Pearson and Lipman 1988) to the contents of GenBank (Bilofsky and Burks 1988) and was found to represent a new B cyclin. We named this gene $C L B 5$, because four B cyclins (CLB1, $C L B 2, C L B 3$, and $C L B 4 \mid$ were already known in budding yeast (Surana et al. 1991). CLB5 can be further identified as a $\mathrm{B}$ cyclin as it contains the conserved FLRR_SK motif (residues 301-307), diagnostic for distinguishing B- and A-type cyclins (O'Farrell and Leopold 1991).

$C L B 5$ is adjacent to one of the other B cyclins, CLB2
(Fig. 1). We tested various plasmids containing CLB5 only, or $C L B 2$ only, for $\ln 1,2,3^{-}$rescue activity and for rescue of a $c l b 1,2^{-}$double mutant [see Materials and methods; the double mutant is lethal (Surana et al. 1991). We found that the CLB2-containing plasmid rescued the $c l b 1,2^{-}$lethality but not the $\ln 1,2,3^{-}$lethality; the CLB5-containing plasmid rescued the $c \ln 1,2,3^{-}$ lethality but not the $c l b 1,2^{-}$lethality (Fig. 1). Thus, $C L B 5$ is qualitatively different from CLB2. The failure of $C L B 2$ to rescue $c \ln 1,2,3^{-}$lethality, together with the fact that no other B-cyclin genes were recovered from our library, suggests that CLB5 is unique among yeast $\mathrm{B}$ cyclins in its ability to rescue $c \ln 1,2,3^{-}$lethality when cloned on a CEN plasmid. Lew et al. (1991) were unable to rescue a $\ln 1,2,3^{-}$strain by overexpressing integrated $C L B 1$ from the strong constitutive glyceraldehyde-3phosphate dehydrogenase promoter, again supporting the inference that $\ln 1,2,3^{-}$rescue may be unique to CLB5. Although addition of CLB5 on a CEN plasmid was adequate at $c \ln$ rescue, but not at $c l b$ rescue, this may simply reflect the time of expression of CLB5 from its natural promoter, rather than the intrinsic potential of the protein. Overexpression of CLB5, or expression from a deregulated promoter, might suffice to rescue $c l b 1 \mathrm{clb} 2$ mutants. These experiments are in progress.

\section{Northern analysis of CLB5}

Four yeast cyclins are known to be subject to cell cycle periodic transcriptional control: $C L N 1$ and $C L N 2$ are maximally expressed just before cell cycle START /Wittenberg et al. 1990; Cross and Tinkelenberg 1991), and $C L B 1$ and CLB2 are maximally expressed before mitosis [Ghiara et al. 1991; Surana et al. 1991). For these genes, the time of expression is consistent with the time of function; CLN1 and CLN2 function to promote START (Richardson et al. 1989), while CLB1 and CLB2 regulate entry into mitosis (Ghiara et al. 1991; Surana et al. 1991). Because the time in the cell cycle when a transcript is abundant may provide some insight into the function of the gene (McKinney and Heintz 1991), we examined $C L B 5$ expression in synchronized cultures. $\mathrm{G}_{1}$ arrest was induced in a $\operatorname{cln} 1 \operatorname{cln} 2 \operatorname{cln} 3 G A L 1:: C L N 3$ strain by incubation in raffinose medium, and cycling was induced by galactose addition, as described (Cross and Tinkelenberg 1991). The defective cln 2 gene in this strain produces a
Figure 1. Restriction map and disruption of CLB5. CE104 and CE110 were among three overlapping CEN plasmid clones recovered that rescued $c \ln 1,2,3^{-}$inviability. CE110 contained intact copies of the $C L B 2$ and $C L B 5$ genes, but $c l n$ rescue activity was unique to $C L B 5$, whereas $c l b 1$ clb2 rescue was unique to $C L B 2$. The re gion of CLB5 between the designated $B s p \mathrm{EI}$ and $E c o \mathrm{RI}$ sites was replaced with the yeast ARG4 gene to generate the clb5::ARG4 allele. (ND) Not determined.

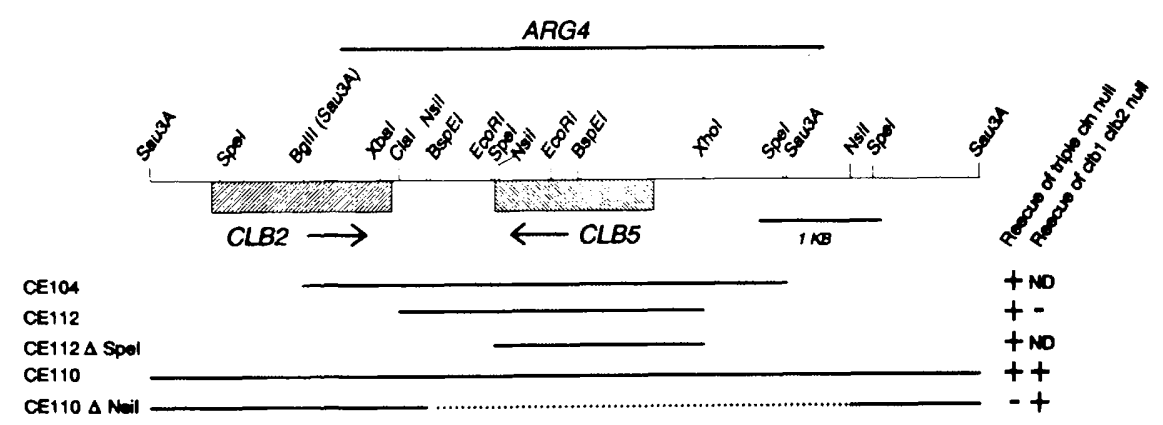




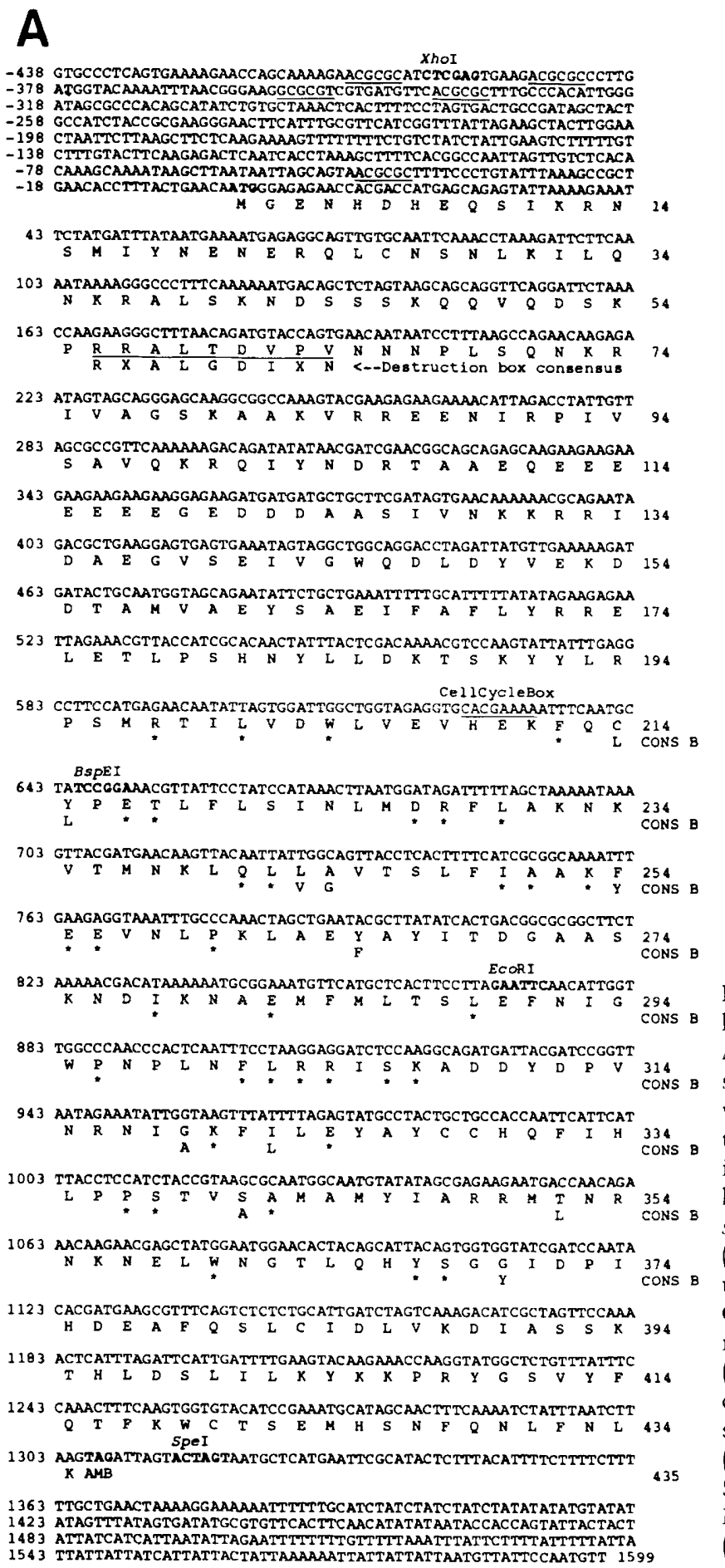

B

CLB5 WQDLDYVEKDDTAMVAEYSAEIFAFLYRRELETLPSHNYLLDKTSKYYLR CLB1 WDDLDEEDCDDPLMVSEEVNDI FDYLHHLEI ITLPNKANLYKHKN - - IK CLB2 WEDLDAEDVNDPFMVSEYVNDI FEYLHQLEVITLPKKEDLYQHRN - - IH CDC13 WDDLDAEDWADPLMVSEYVVDIFEYLNELEIETMPSPTYMDRQKE - - LA MVPDYDPEI FHYMASLERKLAPPPNYMSVQQE - - ID
CIGI 194 238 258 232
192

CLB5 PSMRTILVDWLVEVHEKFOCYPETLFLSINLMDRFLAKNKVTMNKLQLLA CLBI -QNRDILVNWI IKIHNKFGLLPETLYLAINIMDR FLCEEVVQLNRLQLVG CLB2 -QNRDI LVNWLVK I HNKFGLLPET LYLAIN IMDRFLGKELVQLDKLQLVG CDC13 WKMRGILTDWLIEVHSRFRLLPETLFLAV'NI IDRFLSLRVCSLNKLQLVG CIG1 WVTRHMLVDWIVQVOIHFRLLPETLFLAVNLIDRFLSIKVVSLQKVQLVG CLB 3 -FRSTLIDWIVQVHEKFQLLPETLYLCINIIDRYLCKEVVPVNKFQLVG $\begin{aligned} \text { CLB } 4 & \text { - FRRTMIDWLVQLHFRFRLLPETLYLTINIVDRFLSKKTVTLNRFQLVG } \\ * & \ldots * \ldots \ldots * * * * * * * * * * * *\end{aligned}$

CLBS VTSLFIAAKFEEVNLPKLAEYAYITDGAASKNDIKNAEMFMLTSLEFNIG CLB1 TSCLFIASKYFEIYSPSIKHFAYETDGACSVEDIKEGERGILEKLDFQIS CLB2 TSCLFIASKYEEVYSPSIKHFASETDGACTEDEIKEGEKFILKTLKFNLN CDC13 IAALFIASKYEEVMCPSVQNFVMMADGGYDEEEI LQAERYILRVLEFNLA CIGI LSALLIACKYEEIHPPSIY'NFAHVVQG IFTVDEI IRAERYMLMLLDFDIS CLB3 AASLFIAAKYEEINCPTIKDFVYMSENCYSRNDLLDAERTI LNGLEFELG USALFIAAKFEEINCPTLDDLVYMLENT'TRSDI IRAEQYMTDTLEFEIO$$
\text { * } * * *+* x^{*}+{ }^{*}
$$

CLBS WPNPLNFLRRISKADDYDPVNRNIGKFI LEYAYCCHQFIHLPPSTVSAMA CLBI FANPMNFLRRISKADDYDIQSRTLAKFLYEISIVDFKFIGILPSLCASAA CLB2 YPNPMNFLRRISKADDYDIOSRTLAKFLLEISLVDFRFIGILPSLCAAAA CDC13 YPNPMNFLRR ISKADFYDIQTRTVAKYLVEIGLLDHKLLPYPPSOQCAAA CIG1 WPGPMS FLRR ISRAHSYDHDIRMLAKYLQEVTLMDEIFIGAHISFIAATA CLB 3 WPGPMSFLRR ISKADDYEHDTRTLAKYLLESTIMDHRLVSAQPSWLAAGA CLB4 WPGPMPFLRR I SKADDYDFEPRTLAKYLLETT IVEPKLVAAAPSWLAAGA$$
\dot{*} \cdot \dot{x} \dot{x} \dot{x} \dot{x} \dot{x}, * \dot{x}, \dot{x} \ldots \dot{x}, \dot{x}
$$

CLBS MYIARRMTNRNKNELWNGTLQHYSGGIDPIHDEAFQSLCIDLVKDIASS CLB1 MFLSRKMLGKGT - - -WDGNLIHYSGGYTKAKLYPVCQLLMDYLVGSTIH CLB2 MFMSRKMLGKGK - . -WDGNLIHYSGGYTKEELAPVCHMIMDYLVSPIVH CDC13 MYLAREMLGRGP - . -WNRNLVHYSGYEEYQLISVVKKMINYL-QKPVQH CIG1 YYLSYOMLGHLD - . . WTPCHVYYSGYTARQLKPCANI I WECLVDAPNHH CLB 3 YFLSKIILGQYO - - W'SLAHVYYSNYTQEQILPLATIIL

CLB4 YFLSRTILGSND-..WSLKHVFYSGYTSSQIIPLASLIL

Figure 2. (A) CLB5 is a B cyclin. $(D N A)$ The minimal fragment having activity on a CEN plasmid at $\operatorname{cln} 1,2,3^{-}$rescue $\mid$CE 112 $\triangle S$ pe; Fig. $1 /$ is the region between the indicated $X h o l$ and SpeI sites. The DNA between the indicated BspEI and EcoRI sites, which was replaced by the yeast $A R G 4$ gene, falls near the start of the region of cyclin homology; hence, nearly the entire cyclin box is absent in the clb5::ARG4 allele. Sequence was determined for both strands, except in the region -438 to -386 . PPotential transcriptional control elements| Five occurrences of a sequence (ACGCGC and its inverse complement) resembling the MCB are underlined in the $5^{\prime}$ region of the gene. No CCB motifs /CACGAAA, NACGAAA, CNCGAAA, and their inverse complements) are found, with the exception of a single CACGAAAA (underlined), which occurs in the coding region, spanning residues 209-211 of the protein. Previously described CACGAAAA sequences have all been in the $5^{\prime}$-nontranscribed regions (Nasmyth 1985; Nasmyth and Dirick 1991; Ogas et al. 1991). Sequence from -1037 to -438 (data in GenBank, accession no. M91209| showed no further occurrences of CCB or MCB motifs. (Protein) In the cyclin homology region (residues 197-370), we consulted O'Farrell and Leopold (1991) to determine amino acids conserved in at least $90 \%$ of the $14 \mathrm{~B}$ cyclins compared. For those residues, we placed an asterisk under the Clb5 sequence where it matches other B cyclins and placed the B-cyclin consensus amino acid where Clb5 differs. Clb5 matches the consensus at 35 of 46 positions and matches fungal B cyclins at many additional residues, as shown in B. A potential destruction box (Glotzer et al. 1991) is underlined, with the consensus given below the line. Consensus destruction boxes begin at residue 42 ; the $\mathrm{Clb} 5$ destruction box begins at residue 41 or 56 , depending on the true initiator methionine. $(B)$ Alignment of $\mathrm{Clb} 5$ with other yeast $\mathrm{B}$ cyclins. The Clb5 sequence was aligned to all B cyclins known from the yeasts $S$. cerevisiae and $S$. pombe, by use of the CLUSTAL program within PC/GENE (Higgins and Sharp 1988). CLUSTAL places an asterisk under absolutely conserved residues and a dot under well-conserved residues. The Clb5 sequence is underlined at residues where it fails to conform to sequence conserved in most B cyclins (as determined in the legend to $A$ ). 
properly regulated mRNA /Cross and Tinkelenberg 1991), serving as a control for a gene turned on at START. We found that CLB5 RNA is expressed exactly in parallel with cln2 RNA in this protocol (Fig. 3, upper panel). In contrast, CLB2 RNA comes on later and peaks when the CLB5 and cln2 transcripts are near their trough, just preceding nuclear division. This pattern is detectable for two cell cycles in this experiment. The CLB4 transcript is also cell cycle periodic and peaks at a time intermediate between the CLB5 and CLB2 transcripts (data not shown). We have also observed that CLB5 RNA fluctuates exactly in phase with CLN2 RNA in an $\alpha$-factor block-release synchronization protocol with a CLN1 CLN2 CLN3 strain (data not shown). The fact that $C L B 5$ expression peaks earlier in the cell cycle than $C L B 2$ may indicate that $C L B 5$ principally functions at an earlier cell cycle stage.

To further examine the regulation of the CLB5 transcript, we repeated the block-release protocol described above, but released in the presence of nocodazole, a microtubule-depolymerizing agent that prevents mitosis (Jacobs et al. 1988). In this protocol, the first bud emergence occurs with normal timing, but mitosis never occurs and cells arrest in $\mathrm{G}_{2}$ with a single large bud (Jacobs et al. 1988). We found that $c \ln 2$ and CLBS RNAs peak

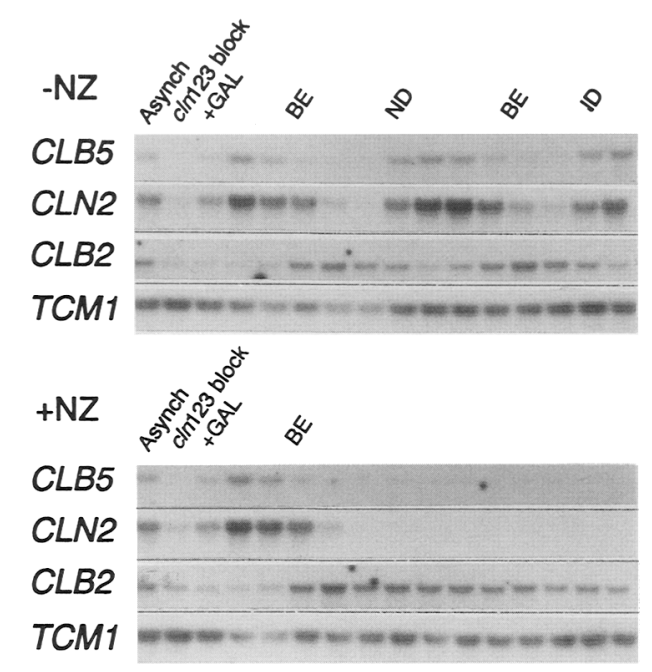

Figure 3. Northern analysis of $C L B 5$ transcription through the cell cycle. $\operatorname{cln} 1$ cln2 cln3 leu2::LEU2::GAL1::CLN3 strains were grown to $\log$ phase in YEP- $3 \%$ galactose at $30^{\circ} \mathrm{C}$ and arrested by 150 min growth in YEP- $3 \%$ raffinose at $30^{\circ} \mathrm{C}$. Cultures were released from cell cycle arrest by the addition of galactose to $3 \%$. At 12 -min intervals thereafter, samples were taken and RNA was isolated. Replicate blots were hybridized with $C L B 5, C L N 2, C L B 2$, and TCM1 (used as a loading control) probes, as indicated. Timing of bud emergence (BE) and nuclear division (ND) was determined by microscopic examination of fixed, sonicated cells, in the latter case stained with DAPI and UV-illuminated. (Bottom) Nocodazole was added $(15 \mu \mathrm{g} / \mathrm{ml}$, final concentration) at the time of galactose addition. (Lane 1) Asynchronous cultures; (lane 2) cells arrested $150 \mathrm{~min}$ at the $\mathrm{cln}^{-}$block; (lane 3) cells arrested 12 min after galactose addition. Subsequent lanes show additional 12-min intervals. with timing equivalent to the nocodazole-free treatment and then decline (Fig. 3, bottom panel). The second peak of these RNAs is not observed. CLB2 RNA also comes up on schedule but, in contrast, remains on at the nocodazole block. These results suggest that the decrease in $C L B 2$ RNA levels requires nuclear division and that the time in the cell cycle when these gene products function is early for CLN2 and CLB5 and late for CLB2.

The initial rise in cln2 RNA levels in this protocol has been ascribed to $C L N$-dependent positive regulation of cln2 RNA (Cross and Tinkelenberg 1991; Dirick and Nasmyth 1991). The Swi4/Swi6 transcriptional regulators have been proposed as mediators of this regulation, acting through the cell cycle box $(\mathrm{CCB})$ target sequences ACGAAA and CCGAAA (Nasmyth and Dirick 1991; Ogas et al. 1991). Whereas CLN1 and CLN2 have such upstream sites, $C L B 5$ has none lexcept in the coding sequence; Fig. 2 legend). The $C L B 5$ transcript had a similar pattern of cell cycle regulation in both $\operatorname{cln} 1,2,3^{-}$ GAL1::CLN3 swi4::URA3 and SWI4 ${ }^{+}$strains (data not shown). The swi4::URA3 allele abolishes CACGAAAAbinding activity and $\mathrm{HO}$ transcription (B.J. Andrews, pers. comm.). Thus, Swi4 is not essential for the periodic transcription of CLB5.

Yeast strains have a second class of genes whose transcripts fluctuate in a cell cycle periodic fashion and peak late in $\mathrm{G}_{1}$. These genes are all involved in DNA replication and include CDC21 (thymidylate synthase), $C D C 9$ (DNA ligase), POL1 (DNA polymerase I), and others (for review, see Andrews and Herskowitz 1990; McKinney and Heintz 1991). All have a sequence motif ACGCGT called the MluI-containing cell cycle box (MCB) in their 5 '-untranscribed region. The MCB is necessary and sufficient for the periodic, late $G_{1}$ pattern of expression of these genes (Gordon and Campbell 1991; Lowndes et al. 1991; McIntosh et al. 1991; Marini and Reed 19921. We examined the sequence of CLB5 for the occurrence of this element and found five ACGCG sites in the $5^{\prime}$-untranslated region of the gene. Four are clustered (three on the sense strand and one on the antisense strand) in the region 407-339 nucleotides upstream of the presumed initiator ATG (Fig. 2); a fifth was found at -47 . No complete MluI sites are present in CLB5; however, the sixth nucleotide of the MluI site may not be critical for MCB activity (McIntosh et al. 1991). The sixth nucleotide of each ACGCG site in CLB5 is a C. Although we have not demonstrated the role of ACGCGC elements in CLB5 transcription, it seems possible that $M C B$ activity contributes to the cell cycle regulation of CLB5 expression.

\section{CLB5 is required for efficient progression through $S$ phase}

To determine the role of $C L B 5$ in cell cycle progression, we disrupted the gene, substituting the region between residues $\mathrm{Y}^{215}$ and $\mathrm{E}^{290}$ with the yeast $A R G 4$ gene (Fig. 1). The substitution removes most of the cyclin box. Strains carrying the deletion have a $20 \%$ increase in cell volume and a $10 \%$ increase in doubling time, compared with 
isogenic wild-type strains. In addition, the proportion of unbudded cells in an exponential culture was significantly lower in strains lacking CLB5 (Table 1). These observations suggested that strains lacking CLB5 are delayed at one or more stages during the budded portion of the cell cycle.

To directly assess the effect of clb5 deletion on cell cycle distribution, we performed flow cytometric DNA analysis on exponentially growing cultures of isogenic wild-type and clb5 strains (Fig. 4, upper panels). Wildtype yeast strains display a characteristic pattern in which over half of the cells are in $\mathrm{G}_{2}$, a smaller portion are in $G_{1}$, and only a small fraction are in $S$ phase. In contrast, clb5 strains exhibit a significant increase in the proportion of cells in $\mathrm{S}$ phase and a diminished fraction of cells in $G_{1}$. The increase in the S-phase fraction suggests that $c l b 5$ strains progress more slowly through $\mathrm{S}$ phase than $C L B 5^{+}$strains. The reduced $\mathrm{G}_{1}$ proportion could also be the result of a delay during progression through $S$ phase, because a delay in $S$ phase leads to larger sized daughter cells at the time of cell separation, reducing the requirement for growth (and time) in $G_{1}$ in the subsequent cycle (Singer and Johnston 1981; Johnston and Singer 1983; for review, see Cross et al. 1989|. The decrease in the $\mathrm{G}_{1}$ population caused by clb5 deletion is likely to work by this indirect mechanism, rather than by directly accelerating the $G_{1} / S$ transition, because $c l b 5$ cells are larger than wild type. Mutations (such as the DAF1-1 allele of $C L N 3$; Cross 1988) that reduce the length of $G_{1}$ by accelerating the $G_{1} / S$ transition are associated with a smaller cell size.

To directly test whether the loss of CLB5 affects the duration of $S$ phase, we examined the kinetics of S-phase transit in CLB5 and $\mathrm{clb} 5$ cultures synchronized by $C L N$ block-release (as in Fig. 3). We obtained flow cytometric DNA profiles at intervals after releasing cells from the $\mathrm{G}_{1}$ block. CLB5 and clb5 strains both budded and entered $S$ phase simultaneously, $\sim 36 \mathrm{~min}$ after release from the $G_{1}$ block (Fig. 5A,B). We detected no indication that clb5 strains entered $S$ phase behind wild-type controls. This suggested that the interval between START and the beginning of $S$ phase was the same in CLB5 and clb5 strains. In CLB5 strains, S phase lasted $\sim 24 \mathrm{~min}$, whereas in clb5 strains, S phase lasted $\sim 48 \mathrm{~min}$. Synchronized cultures therefore confirm that loss of CLB5 slows progression through $S$ phase. We can distinguish between a slowed progression through $S$ phase and a delayed beginning of $S$ phase, because the clb5 mutant culture showed DNA content between $1 \mathrm{~N}$ and $2 \mathrm{~N} / \mathrm{Gl}$ and G2 DNA content, respectively) for a protracted period compared with the CLB5 control. In addition, a similar result was obtained by using $\alpha$-factor to synchronize CLB5 and clb5 CLN1,2,3 $3^{+}$strains; hence, the clb5 S-phase delay is not dependent on the cln-deficient, GAL1::CLN3 background (data not shown).

The FACS data indicate that clb5 strains are delayed during passage through $S$ phase. We wished to confirm this finding by using an alternative method. We used $\alpha$-factor and hydroxyurea to estimate the proportion of cells in a log phase population that lie between the $\alpha$-factor and hydroxyurea execution points (Materials and methods). An execution point is defined as the point in the cell cycle when cells have completed the steps that make them sensitive to an agent, such as $\alpha$-factor or hydroxyurea (Hartwell 1976). Once a cell has passed an execution point, it is insensitive to the corresponding agent for the remainder of the current cell cycle. Because $S$ phase starts shortly after the $\alpha$-factor execution point (Hereford and Hartwell 1974) and ends at about the hydroxyurea execution point (Hartwell 1976), the interval between these points approximates $S$ phase.

In the CLB5 wild-type strain, $20 \%$ of the cells in an exponential culture were between the $\alpha$-factor and hydroxyurea execution points (Table 1). In contrast, in the clb5-deleted strain, $50 \%$ of the cells were in this interval. Given the doubling times of CLB5 and clb5 strains, these percentages allow estimation that $S$ phase requires $17 \mathrm{~min}$ in a CLB5 strain and $48 \mathrm{~min}$ in a clb5 strain (Table 1). These results are in reasonable agreement with the length of $S$ phase estimated from the FACS analysis of synchronous cell cycles (i.e., 24 and $48 \mathrm{~min}$ for CLB5 and $c l b 5$, respectively; Fig. 5).

clb5 deletion does not prolong $G_{2}$

Because CLB5 is a B cyclin, and typically B cyclins pro-

Table 1. The clb5 mutation increases the amount of time between the $\alpha$-factor and the hydroxyurea execution points

Percentage of cells before event

(minutes after cell division that event occurs)

\begin{tabular}{lcccccc} 
& bud emergence & $\begin{array}{l}\alpha \mathrm{F} \text { execution } \\
\text { point }\end{array}$ & $\begin{array}{l}\text { S-phase duration } \\
\text { (min) }\end{array}$ & $\begin{array}{l}\text { HU execution } \\
\text { point }\end{array}$ & $\begin{array}{l}\mathrm{G}_{2}+\text { M duration } \\
\text { (min) }\end{array}$ & $\begin{array}{l}\text { doubling time } \\
\text { [min) }\end{array}$ \\
\hline CLB5 CLB2 & $31 \%(24)$ & $20 \%(15)$ & 17 & $40 \%(32)$ & 68 & 100 \\
clb5 CLB2 & $19 \%(16)$ & $9 \%(7)$ & 48 & $59 \%(55)$ & 55 & 110 \\
CLB5 clb2 & $12 \%(9)$ & ND & ND & $28 \%(22)$ & 80 & 102 \\
clb5 clb2 & $8 \%(7)$ & ND & ND & $40 \%(36)$ & 112 \\
\hline
\end{tabular}

The data in Table 2 were analyzed as described in Materials and methods to yield an estimate of the percentage of cells in an asynchronous population that are before a cell cycle event and the time after cell division that the indicated event occurs. S-phase duration was estimated as hydroxyurea (HU) execution point $(\min )$ minus $\alpha$-factor $(\alpha \mathrm{F})$ execution point $(\min ) . \mathrm{G}_{2}+\mathrm{M}$ duration was estimated as doubling time (min) minus HU execution point (min). (ND) Not determined. 
Figure 4. DNA flow cytometry of asynchronous cultures. Log-phase YEPD cultures of the indicated genotypes were sonicated, fixed, and stained with propidium iodide for flow cytometric analysis. For each genotype, two distinct spore clones were used to confirm that phenotypes observed are characteristic of the genotype. Histograms depict relative DNA content $(x$ axis $)$ vs. cell number (y axis).
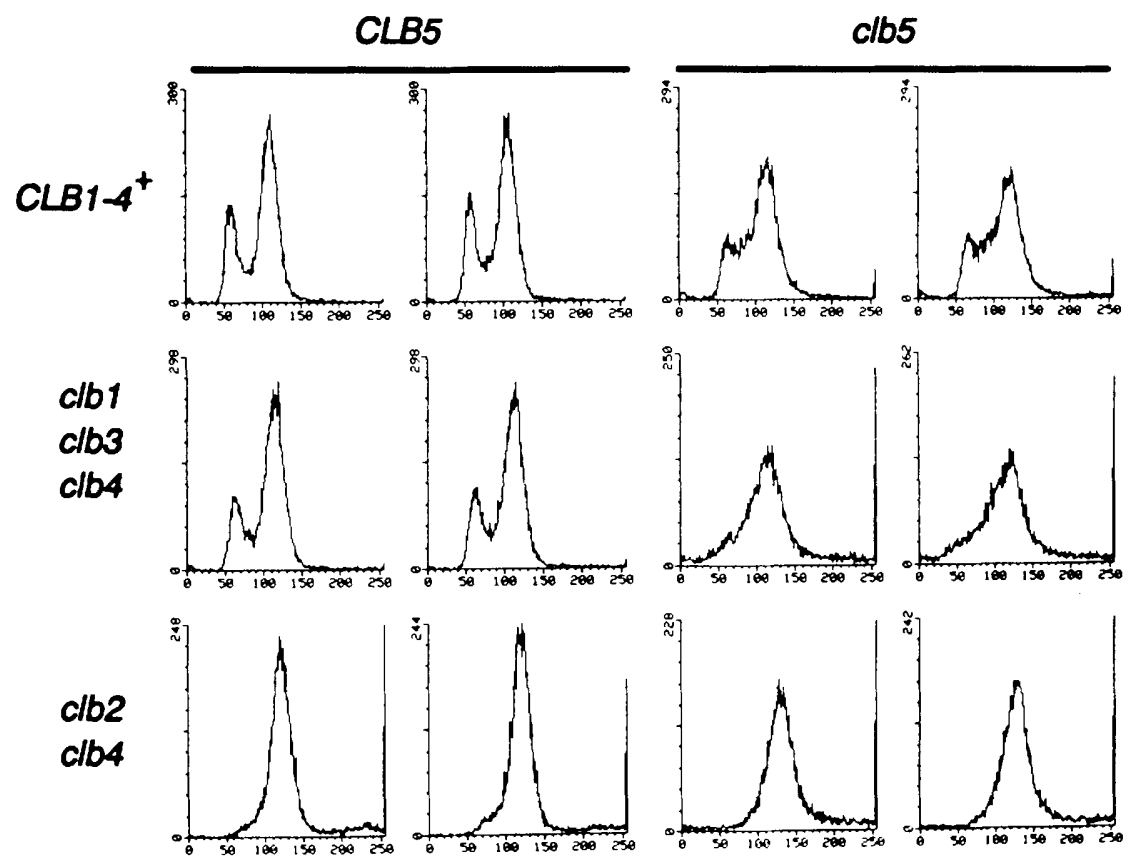

mote $G_{2}$-to-M-phase progression, we examined whether CLB5 deletion prolonged $\mathrm{G}_{2}$. On the basis of FACS analysis of synchronized cells, we estimate that the clb5 strain entered nuclear division $\sim 12$ min after completion of S phase, compared with $\sim 18 \mathrm{~min}$ for CLB5. [Completion of $S$ phase was inferred at the earliest time when all cells were in a well-defined $\mathrm{G}_{2}$ peak (Fig. $5 \mathrm{~A}$ ), while the onset of nuclear division was inferred from the rapid increase in percent binucleate cells (Fig. 5C); see legend to Fig. 5.] Hence, there is no indication from these data that $c l b 5$ deletion caused any delay during $\mathrm{G}_{2}$.

A similar conclusion was reached from the determination of hydroxyurea execution points in exponential cultures. Assuming that $\mathrm{G}_{2}$ starts at the hydroxyurea execution point, the length of $\mathrm{G}_{2}+\mathrm{M}$ (including cytokinesis) can be estimated from the data in Table 1 to be $68 \mathrm{~min}$ for CLB5 and $55 \mathrm{~min}$ for $\mathrm{clb5}$ (see Table 1 footnote). Here, again, $G_{2}$ is possibly shorter, and certainly no longer, in strains lacking CLB5. Note that the $\mathrm{G}_{2}+\mathrm{M}$ estimate is substantially greater than the FACSbased $G_{2}$ estimate, because it includes the interval between nuclear division and cell separation. In contrast, a $c l b 2$ strain was estimated to require $80 \mathrm{~min}$ for the completion of $\mathrm{G}_{2}+M$ (Table 1). This increase in the proportion of the cell cycle after the hydroxyurea-sensitive step is presumably the result of $G_{2}$ delay (Surana et al. 1991). This is consistent with the view that $C L B 2$ has an important role in $G_{2}$, rather than in $S$ phase; the major role of $C L B 5$ appears to be in $S$ phase and not in $\mathrm{G}_{2}$.

\section{Interactions between clb5 and other}

\section{$B$-cyclin mutations}

We reasoned that if other B cyclins acted in concert with CLB5 to promote S-phase transit, then strains bearing combinations of B-cyclin mutations might either have a more pronounced S-phase delay than clb5 single mutants or be altogether unable to transit $S$ phase and, consequently, inviable. We used tetrad analysis to generate all viable combinations of B-cyclin null mutations. The simultaneous deletions $c l b 1 c l b 2$ and $c l b 2$ clb3 are inviable, whereas genotypes $c l b 1 \mathrm{clb} 3 \mathrm{clb} 4$ and $\mathrm{clb} 2 \mathrm{clb} 4$ are viable ( $S$. Reed and D. Lew, pers. comm.). We found that deletion of CLB5 did not cause lethality in conjunction with any viable set of B-cyclin deletions.

We therefore determined the cell cycle distributions of viable combinations of B-cyclin null mutations. We found that exponential cultures of $c l b 1,3,4^{-}$strains have a similar FACS profile to wild-type strains (Fig. 4; cf. top left and central left panels); however, their $G_{1}$ peak is slightly depressed. The deletion of these $\mathrm{B}$ cyclins does not cause a detectable S-phase delay; some delay in $G_{2}$ may be inferred from the diminution of the $G_{1}$ peak. In contrast, clb1,3,4,5- strains display a FACS profile suggestive of a combination of S-phase and $\mathrm{G}_{2}$ delays (Fig. 4, central right panels). These data do not suggest that quadruply deleted strains are significantly more delayed in S phase than $c l b 5$ single mutants, although some effect of clb5 on $\mathrm{G}_{2}$ delay, or of $c l b 1,3,4^{-}$on $\mathrm{S}$-phase delay, cannot be ruled out. Exponential cultures of $c l b 3,4,5^{-}$ strains appear similar by FACS to clb1,3,4,5- strains, indicating that the presence of CLB1 does little to overcome the delays attributable to the simultaneous deletion of $C L B 3, C L B 4$, and $C L B 5$ (data not shown).

Deletion of CLB2 alone (Surana et al. 1991), or CLB2 and $C L B 4$, leads to accumulation of cells in $\mathrm{G}_{2}$ in a logphase culture (Fig. 4, bottom left panels). The FACS profile of $c l b 2,4,5^{-}$strains is also consistent with the accumulation of cells in $G_{2}$, but some $S$-phase delay attributable to the loss of CLB5 function may still be apparent, 
A
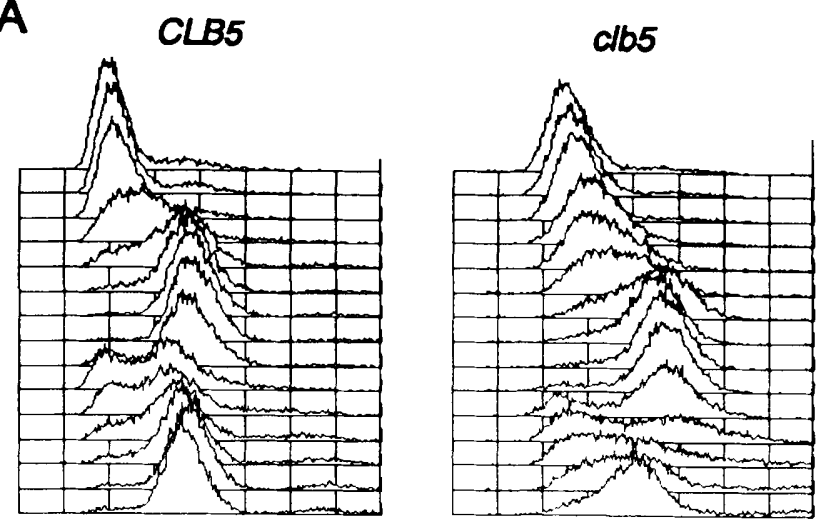

B

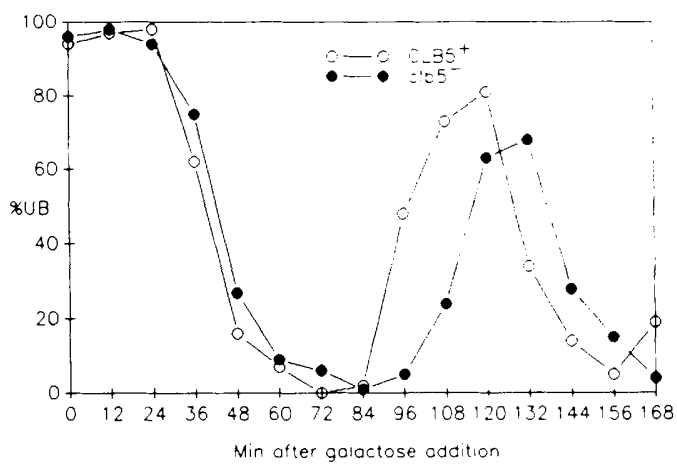

C

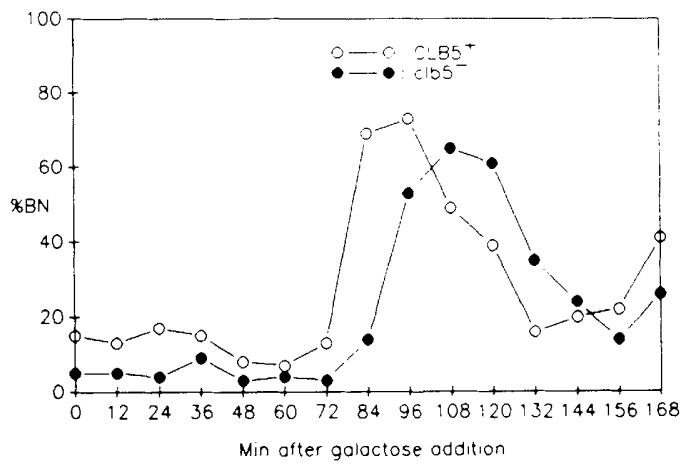

Figure 5. DNA flow cytometry of synchronized cultures following release from arrest in $\mathrm{G}_{1}$. cln $1,2,3^{-}$-deficient strains were synchronized as in Fig. 3. Strains were either CLB5 or clb5::ARG4, as indicated. Initial samples were taken after 150min arrest, and subsequent samples were taken at 12 -min intervals following the addition of galactose. $(A)$ DNA content histograms. The top curve represents the arrested culture; subsequent curves are arranged below. S phase is complete $60 \mathrm{~min}$ after release in CLB5 cells but not until $84 \mathrm{~min}$ after release in clb5 cells. (B) Percent unbudded cells. $(C)$ Percent binucleate cells. Nuclear division occurs $\sim 78 \mathrm{~min}$ after release in CLB5 cells and $\sim 96 \mathrm{~min}$ after release in clb5 cells.

because the $G_{2}$ peak in the latter mutant is shorter and broader (Fig. 4, bottom right panels). To further examine the possible interaction of CLB5 and $C L B 2$, we determined where in the cell cycle the HU execution point occurs in double mutant strains (Table 1, line 4). We found that in a clb2 background, the loss of CLB5 in- creases the interval between bud emergence and the HU execution point from 13 to $29 \mathrm{~min}$, whereas the interval between the $\mathrm{HU}$ execution point and cell division remains virtually unchanged ( 80 vs. $76 \mathrm{~min}$ ). With bud emergence as a rough morphological marker of START (Pringle and Hartwell 1981), this result is consistent with our conclusion from DNA flow cytometry (Fig. 4, bottom) that loss of CLB5 prolongs $\mathrm{S}$ phase in a $\mathrm{clb} 2$ background while having no incremental effect on the $\mathrm{G}_{2}$ delay attributable to the loss of $C L B 2$.

\section{Is CLB5 functionally redundant with the CLN genes?}

Because we discovered CLB5 on the basis of its ability to rescue $\operatorname{cln} 1,2,3^{-}$yeast when overexpressed and then found that its transcript is present at times in the cell cycle coinciding with those of CLN2 (and CLN1), we were curious to determine whether it could be demonstrated to have $C L N$-like functions. We tested all combinations of cln deletions with the CLB5 deletion and found that CLB5 was not essential in strains bearing any viable combination of $c$ ln deletions (Fig. 6, left panels). However, when cells were tested on YEP-glycerol media, $\operatorname{cln} 1$ cln 2 clb5 strains were nearly inviable, whereas cln1 cln2 CLB5 strains were fully viable (Fig. 6, right panels). This observation is suggestive of partial functional redundancy between CLB5 and $C L N$ genes: cln $1,2^{-}$strains rely on both CLN3 and CLB5 for growth on glycerol media. Deletion of $C L B 2$ in the $\operatorname{cln} 1,2^{-}$

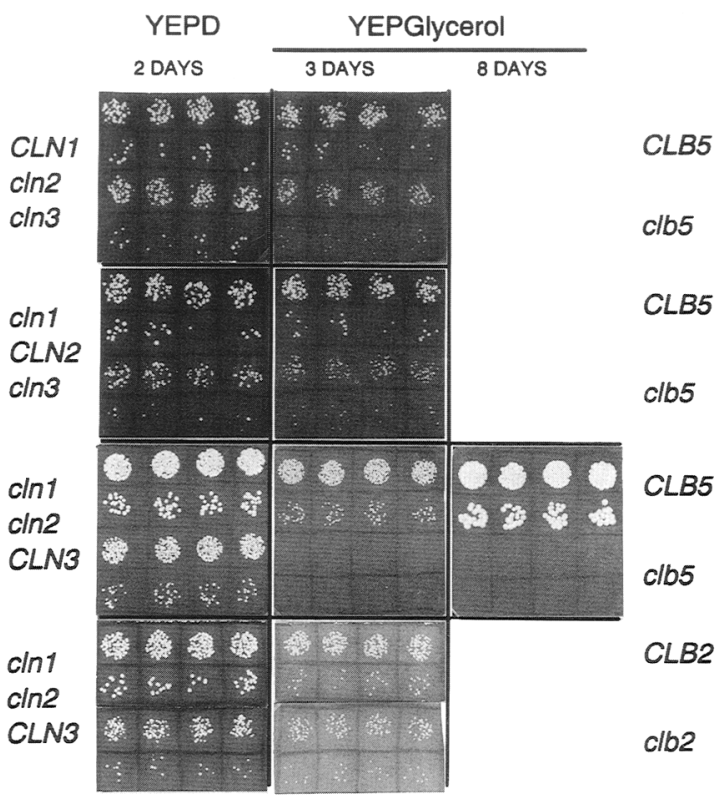

Figure 6. $c \ln 1 c \ln 2 c l b 5$ strains are nearly inviable on glycerol media. Strains of the indicated genotypes were serially diluted and plated at two densities on YEP media supplemented with either $2 \%$ glucose (YEPD) or $3 \%$ glycerol. Photographs were taken after growth for the indicated number of days. $c \ln 1 \mathrm{cln} 2$ clb5 strains formed detectable colonies on YEP-glycerol after $\sim 1$ week of growth, with a plating efficiency of $\sim 5 \%$ (glycerol/ glucose). 
background did not impair viability on glycerol (Fig. 6 , bottom panels). Diploids made by mating $c \ln 1 \mathrm{cln} 2 \mathrm{clb5}$ strains to a $\rho^{0}$ (mitochondrial deficient) $c \ln 3$ strain were viable on glycerol media, hence, the glycerol lethality of $c \ln 1 c \ln 2 c l b 5$ strains is not the result of a defect in their mitochondrial DNA.

Leopold and O'Farrell (1991) reported that overexpression of the $D$. melanogaster cdc2 gene could rescue $\operatorname{cln} 1,2,3^{-}$yeast strains. They speculated that the Drosophila Cdc2 protein was interacting with an unidentified cyclin. We have found that rescue of $c \ln 1,2,3^{-}$yeast by Drosophila $c d c 2$ is dependent on CLB5. $\operatorname{cln} 1,2,3^{-}$clb5 GAL1::CLN3 yeast strains transformed with the Drosophila $c d c 2$ plasmid are inviable on glucose, yet isogenic $C L B 5$ transformants are viable (data not shown). This result further supports the idea that CLB5 function may overlap with $C L N$ gene functions.

\section{Discussion}

\section{CLB5 functions to promote $S$ phase}

We report the discovery of a fifth B cyclin in budding yeast. Although this gene is not essential, its deletion significantly depresses the rate at which cells replicate chromosomal DNA. DNA flow cytometry of both exponential and synchronized cultures shows that clb5 strains are slowed during progression through $S$ phase. Also, we have shown that the proportion of the cell cycle falling between the $\alpha$-factor and hydroxyurea execution points expands in $c l b 5$ strains. It is plausible to infer that the $\alpha$-factor execution point approximates the start of $S$ phase (Hereford and Hartwell 1974) and the hydroxyurea execution point marks the completion of $\mathrm{S}$ phase, in both clb5 and wild-type strains (Hartwell 1976). Hence, both experimental approaches indicate that CLB5 functions to promote S-phase transit. CLB5 is the only yeast cyclin whose deletion causes prolonged $S$ phase. Deletion of other B cyclins either prolongs $G_{2}(C L B 2)$ or has little effect on cell cycle distribution (CLB1,CLB3, and $C L B 4$; Fig. 4), whereas deletion of any two CLN genes does not cause an S-phase delay detectable by DNA flow cytometry (data not shown). Deletion of the B-cyclin cig $1^{+}$in $S$. pombe causes a delay during $G_{1}$ or in the $\mathrm{G}_{1} / \mathrm{S}$ transition but does not affect the rate of S-phase progression (Bueno et al. 1991).

The loss of CLB5 seems to affect the overall rate of progression through $S$ phase. In contrast, other known cyclins promote transitions between discrete phases of the cell cycle, such as the START event (CLNs; Richardson et al. 1989), the $\mathrm{G}_{2} / \mathrm{M}$ transition (Murray and Kirschner 1989; Nurse 1990; Hartwell 1991), and meiotic induction (Westendorf et al. 1989). However, CLB5 may not act throughout $S$ phase. An effect on the rate of $S$-phase progression could be caused by a defect in initiation (e.g., owing to the to use of a smaller number of origins of replication). Moreover, we note the possibility that CLB5 affects the efficiency of S-phase transit by acting at a time other than $S$ phase, for example, during $\mathrm{G}_{1}$, or $\mathrm{G}_{2}$ of the preceding cycle.
We considered that slow S-phase transit in clb5 strains might result from defective regulation of the genes involved in DNA replication and expressed under the control of the DSCl-binding activity and the $\mathrm{MCB}$ (Lowndes et al. 1991; for review, see McKinney and Heintz 1991). In the synchronous time course shown in Figure 5, we examined the regulation of $C D C 21$ (an MCB gene). CDC21 RNA accumulation peaked with similar levels and kinetics in CLB5 and clb5 strains (data not shown). We also did not detect a significant defect in histone $\mathrm{H} 2 \mathrm{~A}$ transcription in clb5 strains. $\mathrm{H} 2 \mathrm{~A}$ is an S-phasetranscribed gene not under MCB control (for review, see Osley 1991). In light of these results, it seems unlikely that the basis for the prolonged S phase of clb5 strains is a defect in the transcriptional control of gene products involved in DNA synthesis. Consistent with this conclusion is the observation that the $c l b 5$ deletion fails to affect DSCl DNA-binding activity ( $\mathrm{L}$. Johnston, pers. comm.).

In human cells there is some evidence for the involvement of a cyclin-dependent kinase in DNA synthesis (Blow and Nurse 1990; D'Urso et al. 1990; Furakawa et al. 1990; Fang and Newport 1991). In higher eukaryotes it appears that $c d c 2$ has multiple homologs [called cdks (Tsai et al. 1991)]. Distinct kinases may be involved in $\mathrm{S}$-phase and $\mathrm{M}$-phase promotion (Fang and Newport 1991|. Multiple cyclin/cdk complexes are present during $\mathrm{S}$ phase, and at least three of them (cyclin A/cdc2, cyclin $\mathrm{A} / \mathrm{cdk} 2$, and cyclin $\mathrm{E} / \mathrm{cdk} 2$ ) are catalytically active at this time (Pines and Hunter 1990b; J. Roberts, pers. comm). No A-type or E-type cyclins are known in budding yeast. Perhaps $C L B 5$ plays a role in yeast similar to the role played by cyclin A or cyclin $\mathrm{E}$ in human cells. In addition, it remains to be tested whether CLB5 activates Cdc28 kinase.

\section{Does CLB5 function elsewhere in the cell cycle?}

Although CLB5 was discovered on the basis of $\operatorname{cln} 1,2,3^{-}$ rescue, we cannot be sure whether CLB5 functions in concert with $C L N \mathrm{~s}$ in their role in START. The fact that the CLB5 transcript appears and disappears in synchrony with the CLN2 transcript, together with the fact that extra copies of the CLB5 gene under the control of the natural promoter rescue $\ln 1,2,3^{-}$strains, suggests that the $\mathrm{Clb} 5$ protein may be present early enough to have a role in START. The fact that strains lacking CLN1 and CLN2 require CLB5 for viability on glycerol suggests that $C L B 5$, like $C L N 3$, can promote $C L N$-dependent events. A similar conclusion is implied by the fact that $\operatorname{cln} 1,2,3^{-}$strains require $C L B 5$ for rescue by the $D$. melanogaster $c d c 2$ gene.

Does CLBS have an additional role in promoting the $\mathrm{G}_{2} / \mathrm{M}$-phase transition? The data presented (Figs. 4 and 5 ; Table 1) do not suggest any delay during $\mathrm{G}_{2}$ in clb5 mutants. However, the presence of a potential mitotic destruction box (Glotzer et al. 1991) in Clb5 suggests that the protein may persist until $\mathrm{M}$ phase, consistent with a possible role in $\mathrm{G}_{2}$. Finally, CLB5 appears to be required for the normal progression through meiosis $(\mathrm{C}$. 
Epstein and F. Cross, unpubl.,, although we have not determined at which meiotic stage $C L B 5$ becomes essential.

\section{Materials and methods}

Strains and media

All strains were isogenic with BF264-15D (trp1-1a leu2-3,112 ura3 ade1 his2). A nonreverting null allele of $A R G 4$ was installed in the BF264-15D background with pmlc12PstARG4BglFill[BamURA3] (Sun et al. 1989). The $c \ln 1$ and $c \ln 3$ deletions were as described (Cross and Tinkelenberg 1991), whereas the cln2 deletion was made by a similar procedure to the $c \ln 2$ deletion in that reference, except that it extended between the SphI site at -504 and the SpeI site at amino acid 162 of the CLN2-coding sequence. This new cln2 allele was demonstrated to be null for $C L N$ function as described (Cross and Tinkelenberg 1991). Strains bearing null alleles of CLB1 (Ghiara et al. 1991), CLB2, CLB3, and CLB4 (unpubl.) were kindly supplied by S. Reed and D. Lew (Scripps Research Inst., La Jolla, CA; unpubl.). The swi4::URA3 allele consisted of a duplication of an internal BamHI fragment of SWI4, with the URA3 between the duplicated sequences. This construct was provided by B. Andrews (University of Toronto, Canada) and was introduced into the BF264-15D background by J. McKinney (Rockefeller University, New York). The structures of all disruptions were confirmed by Southern blotting. Hydroxyurea (Sigma) was used in solid media at $0.2 \mathrm{~m}$. Nocodazole (Sigma) was used in liquid media at $15 \mu \mathrm{g} / \mathrm{ml}$, from a dimethylsulfoxide (DMSO) stock at $10 \mathrm{mg} / \mathrm{ml}$. Standard techniques were employed for strain constructions (Sherman et al. 1989).

\section{Construction of CEN plasmid library}

We cloned CLB5 fortuitously while attempting to clone an unlinked dominant mutation, the CLN bypass mutation (CBM8), whose phenotypes include cell division and colony formation in a $c \ln 1,2,3^{-}$background. A full description of these mutations is in preparation. Briefly, CBM 8 was isolated as a spontaneously occurring mutation, which conferred viability on a strain whose genotype was $c \ln 1 \operatorname{cln} 2 \operatorname{cln} 3$ [pGAL1::CLN3/URA3]. After the original isolation and backcross of $C B M 8$, it was maintained in the presence of GAL1::CLN3, avoiding selection of further modifiers of viability of the $c \ln 1,2,3^{-}$condition.

We sought to clone $C B M 8$ by making a library in a yeast $C E N$ plasmid, from genomic DNA isolated from strain YCE933-1C (cln1 CLN2 cln3 CBM8 $8^{4 \text { th Backcross }}$ ). We then isolated plasmids from this library that conferred viability on $\operatorname{cln} 1,2,3^{-}$strains. We included $C L N 2$ in the library as a positive control. We made our library in a novel yeast cloning vector, pCE101, which was made from pRS314 (Sikorski and Heiter 1989) by substituting a pBR322 ORI for the existing pUC ORI.

Yeast YCE933-1C was inoculated into 1 liter of YEPD and cultured to an OD of 1.15. Yeast DNA was then isolated essentially as described in Holm et al. (1986). DNA was $1 / 16$ underdigested with Sau3A, phenol extracted, RNase treated, and precipitated with polyethylene glycol (PEG) to eliminate residual RNA. The pellet was recovered and run over a $10-30 \%$ glycerol gradient for $5 \mathrm{hr}$ at $40,000 \mathrm{rpm}$ in an SW40 rotor. The gradient was fractionated, and a fraction was retained having a modal DNA fragment length of $\sim 12 \mathrm{~kb}$.

pCE101 was cut with BamHI, treated with calf intestinal phosphatase, and combined, at a concentration of $3 \mu \mathrm{g} / \mathrm{ml}$, with the glycerol gradient-fractionated yeast DNA. The mixture was ligated overnight at $15^{\circ} \mathrm{C}$ with T4 DNA ligase and transformed into Escherichia coli strain DH5 $\alpha$. Bacterial colonies were rinsed off of the Luria broth (LB)/ampicillin plates and pooled from 50 independent transformations and platings of the ligated DNA, cultured for $2 \mathrm{hr}$ with an added $100 \mathrm{ml}$ of $\mathrm{LB}(50 \mu \mathrm{g} / \mathrm{ml}$ of ampicillin), and plasmid DNA was prepared by the alkaline lysis method.

\section{Isolation of CLB5 gene from library}

Library DNA was transformed into yeast strain YCE960-3C [cln $1 c \ln 2 \operatorname{cln} 3$ [pGAL1::CLN3/URA3], and transformants were selected on YcGal-trp. Once colonies had grown up, replicas were taken to YEPD agar. Secondary YEPD replicas were taken from the primary replicas after $24 \mathrm{hr}$ of growth. These were allowed to grow for 2-3 days, although [pCLN2/TRP1] clones formed robust patches after 1 day of growth. Candidate clones were picked from the secondary YEPD replicas, and the colony was purified on YcGal-trp-ura. Growth on YEPD was demonstrated to be dependent on inheritance of a TRP1/CEN plasmid based on cosegregation, following plasmid loss during nonselective growth. Plasmids were recovered from $1.5-\mathrm{ml}$ overnight YEPD cultures, as described (Ausubel et al. 1987).

Overall, from two independent libraries made from the same glycerol gradient fraction, we recovered eight distinct clones of CLN2 (a total of 42 times), three distinct clones of CLB5 (a total of 3 times\}, and a single clone bearing $M P K 1$, found previously to suppress $c \ln 1,2,3^{-}$lethality in a high-copy plasmid (O. Fields and J. Thorner; B. Futcher; both pers. comm.). Clones of CLN2 were identified on the basis of hybridization to a radiolabeled $C L N 2$ probe. The CLB5 and MPK1 genes were subcloned into the integrating vector RS304, yielding pCE105 and pCE117, respectively. These were each linearized at a unique site in the insert and transformed into diploid YCE957 (cln $1 / c \ln 1 \mathrm{cln} 2 /$ cln2 $c \ln 3 / c \ln 3$ CBM8 [pGAL1::CLN3/URA3]. Transformants were recovered on YcGal-trp, sponulated, and dissected. Southern blots confirmed that the RS304 derivatives had integrated by homologous recombination at the CLB5 and MPK1 loci, as expected. $C B M 8$ was not linked to either $C L B 5$ or $M P K 1$; hence, our CLB5 and MPK1 clones represent wild-type DNA.

\section{Plasmids, subcloning, and sequencing}

pCE104 was one of the CLB5 plasmids isolated from our CEN plasmid library. pCE111 and pCE112 were made by subcloning the pCE 104 entire insert and XhoI-ClaI fragments, respectively, into pRS314 (Sikorski and Hieter 1989). pCE111 $\Delta C l a I$ and pCEl $12 \Delta$ SpeI were derived from their respective parent plasmids by limit digestion and recircularization. pCE110 was another of the CLB5 plasmids isolated from the library. Restriction mapping, sequencing, and hybridization experiments revealed that it contained the CLB2 gene, as well as the CLB5 gene. pCE $110 \triangle N$ siI, lacking the CLB5 gene, was derived from pCEllo.

To make a null allele of $C L B 5$, we partially digested CE111 $\triangle C l a$ I with EcoRI and ligated it to EcoRI-digested pMLC28Pst6$A R G 4$ (Sun et al. 1989). The ligation mixture was transformed into $E$. coli, and transformants were selected on $\mathrm{LB}, 50 \mu \mathrm{g} / \mathrm{ml}$ of ampicillin, and $34 \mu \mathrm{g} / \mathrm{ml}$ of chloramphenicol. Several of these transformants were restriction mapped, and one was selected in which the $A R G 4$ plasmid had been cloned into the EcoRI site at residues 290/291 of CLB5, with the orientation $5^{\prime} C L B 5 \rightarrow$ camR $\rightarrow A R G 4 \rightarrow 3^{\prime} C L B 5$. This was partially digested with $B s p \mathrm{EI}$, and a fragment lacking the $B s p \mathrm{EI}$ fragment spanning residues 216-291 of CLB5, plus part of the camR gene, was gel purified and recircularized with T4 DNA ligase. The resulting plasmid, clb5::ARG4 $\triangle B s p E I$, was digested with $X h o I$ and SpeI and transformed into arg 4 strains. Integration was demon- 
strated to be at the CLB5 locus by Southern blotting. pclb5:: $A R G 4 / C E N / T R P 1$ was also transformed into $c \ln 1,2,3^{-}$yeast as an intact CEN plasmid and shown to have no activity at $\operatorname{cln} 1,2,3^{-}$rescue.

Dideoxy sequencing with Sequenase (U.S. Biochemical) was performed according to the manufacturer's instructions. Double-stranded DNA was sequenced on both strands, by use of exonuclease III deletion derivatives of pCE111 and pCE112, restriction enzyme deletion derivatives, and custom synthesized primers.

\section{clb1 clb2 rescue by $p C E N / C L B 2$}

Diploid YCE997 (clb1::URA3/CLB1 clb2::LEU2/CLB2) was transformed with pCE110, pCE112, and pCE110 $\Delta$ NsiI (Fig. 1). From each transformation, a colony was picked, cultured in YcD-trp liquid, sporulated, and dissected. Replicas were taken from the dissection agar to score clb1::URA3, clb2::LEU2, and the TRP1/CEN plasmid. From 997[pCE110] haploid progeny strains, $5 \mathrm{Ura}^{+} \mathrm{Leu}^{+} \mathrm{Trp}^{+}$colonies were found among $22 \mathrm{Trp}^{+}$ spores $(23 \%)$. From $997\left[\right.$ pCEl $10 \Delta N$ sil], $2 \mathrm{Ura}^{+} \mathrm{Leu}^{+} \mathrm{Trp}^{+}$colonies were found among $7 \operatorname{Trp}^{+}$spores $(29 \%)$. From 997[pCE112], no $\mathrm{Ura}^{+} \mathrm{Leu}^{+} \operatorname{Trp}^{+}$colonies were found among $33 \mathrm{Trp}^{+}$spores, although $44 \%$ of the viable progeny were $\operatorname{Trp}^{*}$, $37 \%$ were $\mathrm{Ura}^{+}$, and $28 \%$ were $\mathrm{Leu}^{+}$. If pCE 112 rescued $c l b 1$ clb2 mutants, then one-fourth of $\operatorname{Trp}^{+}$spores (i.e., 8.25 ) should be $\mathrm{Ura}^{+} \mathrm{Leu}^{+}$, given the independent assortment of $C L B 1$ and $C L B 2$. The finding that none is significant $\left(\mathrm{X}^{2}=11.00, P<0.005\right)$.

\section{Determination of $\alpha$-factor and hydroxyurea execution points}

The arrest morphology owing to $\alpha$-factor treatment is a large unbudded cell (Pringle and Hartwell 1981). Therefore, a cell past the $\alpha$-factor execution point at the time of plating on $\alpha$-factorcontaining solid medium will divide, and each of the new cells will arrest without budding, resulting in an adjacent pair of large unbudded cells. A cell before the $\alpha$-factor execution point will arrest as a single, large unbudded cell.

The arrest morphology owing to hydroxyurea treatment is a large budded cell (Pringle and Hartwell 1981). Therefore, a cell past the hydroxyurea execution point at the time of plating on hydroxyurea-containing solid medium will divide, and each of the new cells will bud and arrest, resulting in an adjacent pair of large budded cells. A cell before the hydroxyurea execution point will arrest as a single large budded cell.

Exponentially growing cultures of YCE1029-12B (MATa bar1 $C L B 5$ ) or YCE1029-10B (MATa bar1 clb5::ARG4) in YEPD medium were sonicated and plated on YEPD, YEPD $+10^{-8} \mathrm{M}$ $\alpha$-factor, or YEPD $+0.2 \mathrm{M}$ hydroxyurea (Hartwell 1976). After $4-\mathrm{hr}(3.5 \mathrm{hr}$ in one experiment $)$ incubation at $30^{\circ} \mathrm{C}$, the plates were examined microscopically. By the end of the incubation on the control YEPD plate, $>90 \%$ of the cells had divided and budded again at least once, so we did not consider viability to be a significant concern in the analysis. Although ideally all cells on the hydroxyurea plate should be either two or four cells plus buds per microcolony (Hartwell 1976), 10\% of the cells were found in the one, three, and five cells plus buds per microcolony categories. The one-cell category was considered to be before the hydroxyurea execution point; the three- and five-cell categories were considered to be past the execution point. Similarly for $\alpha$-factor, ideally all cells should be one or two cells per microcolony; we observed $\sim 10-15 \%$ of cells in the three-, four-, or five-cell categories. These were considered to be past the $\alpha$-factor execution point in the analysis. The percentage of budded cells was determined at the time of plating. A total of 100 cells each were scored for two independent cultures in three (hydroxyurea execution point) or two ( $\alpha$-factor execution point) separate experiments, and the data were pooled (Table 2). To calculate the proportion of the total cell cycle time at which various events occurred from the percentage of cells in the population past those events, we employed the age-distribution function (Mitchison 1971) $E x(F)=1-\ln (2-F) / \ln 2$, where $F$ is the fraction of cells before the execution point, and $E x(F)$ is the point in the cell cycle at which the execution point occurs (in units of cell cycle times, from 0 to 11 . The time from cell division to the execution point in minutes was calculated by multiplying $E_{x}(F)$ by the doubling time of the strain. The hydroxyurea execution point was determined similarly for a clb2::LEU2 strain.

\section{Northern blotting}

Northern blotting was performed as described in Cross and Tinkelenberg (1991). cln 1,2,3- leu2::LEU2::GAL1::CLN3 cells were synchronized by incubating in YEP-3\% raffinose for 150

Table 2. Cell division and budding upon plating wild-type and clb5 yeast on solid media containing inhibitors

\begin{tabular}{|c|c|c|c|c|c|c|c|c|}
\hline \multirow[b]{2}{*}{ Strain } & \multirow[b]{2}{*}{ Time (hr) } & \multirow[b]{2}{*}{ Medium $^{a}$} & \multicolumn{5}{|c|}{ Cells + buds per microcolony (S.E.M.) } & \multirow{2}{*}{$\begin{array}{l}\text { Number of } \\
\text { experiments } \\
\text { forming mean }\end{array}$} \\
\hline & & & 1 & 2 & 3 & 4 & $>4$ & \\
\hline \multirow{3}{*}{ CLB5 CLB2 } & 0 & & $31(3)$ & $67|3|$ & $2(1)$ & $2(0)$ & $0(0)$ & 6 \\
\hline & 4 & $\alpha \mathrm{F}$ & $20(3)$ & $65(4)$ & $6(2)$ & $7(2)$ & $2(2)$ & 4 \\
\hline & 4 & $\mathrm{HU}$ & $3|0|$ & $33(2)$ & $4(2)$ & $58(3)$ & $2(1)$ & 6 \\
\hline \multirow[t]{3}{*}{ clb5 CLB2 } & 0 & & $19(2)$ & $76(2)$ & $3\{1\}$ & $2\langle 1\rangle$ & $0\langle 0\}$ & 6 \\
\hline & 4 & $\alpha \mathrm{F}$ & $8|0|$ & $79(2)$ & $6(0)$ & $6(2)$ & $1|0\rangle$ & 4 \\
\hline & 4 & $\mathrm{HU}$ & $2\langle 1\rangle$ & $56(3)$ & $2(1)$ & $36(2)$ & $5(1)$ & 6 \\
\hline \multirow[t]{2}{*}{ CLB5 clb2 } & 0 & & $12(2)$ & $86(3)$ & $1(1)$ & $1(1)$ & $0(0)$ & 4 \\
\hline & 4 & $\mathrm{HU}$ & $0(0)$ & $25(2)$ & $3(1)$ & $70(1)$ & $2(1)$ & 4 \\
\hline \multirow[t]{2}{*}{$c l b 5 c l b 2$} & 0 & & $8(3)$ & $89(2)$ & $2(1)$ & $2(2)$ & $0(0)$ & 4 \\
\hline & 4 & $\mathrm{HU}$ & $1(2)$ & $35|7|$ & $4(1)$ & $57(6)$ & $3(1)$ & 4 \\
\hline
\end{tabular}

The number of cells + buds formed by each cell plated was determined by microscopic examination of cells plated on appropriate media (see Materials and methods). For each condition in each experiment, 100 cells were scored. The means and standard errors (S.E.M.) of the data are shown, and the number of replicate experiments used to calculate the mean is indicated.

${ }^{a}(\alpha F) \alpha$-Factor; (HU) hydroxyurea. 
min. Galactose was added to 3\% to start the cycle. Nocodazole was used at $15 \mu \mathrm{g} / \mathrm{ml}$. DNA fragments used as probes were as follows: CLB5, the 462-bp ECoRI fragment; CLB2, the 767-bp $B g I I I-C l a I$ fragment; CLB4, the 500-bp SpeI-SspI fragment, from a clone kindly supplied by B. Futcher /Cold Spring Harbor Lab, New York); CLN2 and TCM1, as described (Cross and Tinkelenberg 19911.

\section{Determination of cell cycle parameters}

Flow cytometric DNA quantitation was determined as follows: Cells were stained with propidium iodide and prepared for FACS analysis by use of a Becton Dickinson FACScan, as described (Lew et al. 1992). In most experiments, 10,000 cells were examined. Events were either live-gated to have a DNA fluorescence above background or gated after acquisition on the basis of forward and side scatter, to exclude cell debris. In the former case (Fig. 5), all 10,000 events are plotted in the DNA content histograms; in the latter (Fig. 4), up to $\sim 20 \%$ of the events are discarded. The profiles were affected very little by the gating method chosen. When the latter method was used, the $y$ axes were adjusted to compensate for the fact that different numbers of events are represented on different histograms. A constant proportion of the cell population corresponds to a constant area in the histogram, regardless of the gating method used. For FACS analysis of synchronized cells, $\operatorname{cln} 1,2,3^{-}$- deficient cells were synchronized exactly as in Northern blots, or by treating a bar1 MATa strain with $10^{-7} \mathrm{M} \alpha$-factor (Sigma) for $120 \mathrm{~min}$.

Doubling times were determined from log-phase cultures. $\mathrm{OD}_{660}$ readings were taken at intervals, log transformed, and regressed versus time. Electronic cell volumes were determined as described (Cross 1988).

\section{Acknowledgments}

We acknowledge B. Andrews, C. Blake, B. Futcher, P. Leopold, D. Lew, J. McKinney, M.A. Osley, S. Reed, H. Richardson, N. Schultes, and R. Sikorski for yeast strains and plasmids. Special thanks go to J. Hirsch for advice on library construction, to J. McKinney for supplying the Northern blot in Figure 3 and for helping with hybridizations, and to C. Neyt for instruction with DNA sequencing. We are grateful to R. Deshaies, B. Futcher, L. Johnston, D. Lew, S. Reed, and J. Thorner for communicating results before publication. We also thank S. DiNardo, J. Roberts, and D. Wilson for critical comments on the manuscript. C.B.E. was partially supported by a National Research Service Award Training Grant (GM07982-10). F.R.C. is a Lucille P. Markey Scholar. This work was supported by the Lucille P. Markey Charitable Trust and by the Rockefeller University.

The publication costs of this article were defrayed in part by payment of page charges. This article must therefore be hereby marked "advertisement" in accordance with 18 USC section 1734 solely to indicate this fact.

\section{References}

Andrews, B.J. and I. Herskowitz. 1990. Regulation of cell cycledependent gene expression in yeast. $J$. Biol. Chem. 265: 14057-14060.

Ausubel, F.M., R. Brent, R.E. Kingston, D.D. Moore, J.G. Seidman, J.A. Smith, and K. Struhl. 1987. Current protocols in molecular biology. Wiley Interscience/Greene, New York.

Blow, J.J. and P. Nurse. 1990. A cdc2-like protein is involved in the initiation of DNA replication in Xenopus egg extracts. Cell 62: 855-862.
Bueno, A., H. Richardson, S.I. Reed, and P. Russell. 1991. A fission yeast $\mathrm{B}$-type cyclin functioning early in the cell cycle. Cell 66: 149-159.

Cross, F.R. 1988. DAF1, a mutant gene affecting size control, pheromone arrest, and cell cycle kinetics of Saccharomyces cerevisiae. Mol. Cell. Biol. 8: 4675-4684.

-1990. Cell cycle arrest caused by CLN gene deficiency in Saccharomyces cerevisiae resembles START-I arrest and is independent of the mating-pheromone signalling pathway. Mol. Cell. Biol. 10: 6482-6490.

Cross, F.R. and A.H. Tinkelenberg. 1991. A potential positive feedback loop controlling CLN1 and CLN2 gene expression at the start of the yeast cell cycle. Cell 65: 875-883.

Cross, F.R., J. Roberts, and H. Weintraub. 1989. Simple and complex cell cycles. Annu. Rev. Cell Biol. 5: 341-395.

Dirick, L. and K. Nasmyth. 1991. Positive feedback in the activation of $G_{1}$ cyclins in yeast. Nature 351: 754-757.

D'Urso, G., R.L. Marraccino, D.R. Marshak, and J.M. Roberts. 1990. Cell cycle control of DNA replication by a homologue from human cells of the p34cdc2 protein kinase. Science 250: $786-791$.

Fang, F. and J.W. Newport. 1991. Evidence that the $G_{1}-S$ and $\mathrm{G}_{2}-\mathrm{M}$ transitions are controlled by different cdc 2 proteins in higher eukaryotes. Cell 66: 731-742.

Furukawa, Y., H. Piwnica-Worms, T.J. Ernst, Y. Kanakura, and J.D. Griffin. 1990. cdc2 Gene expression at the $G_{1}$ to $S$ transition in human $T$ lymphocytes. Science 250: 805-808.

Ghiara, J.B., H.E. Richardson, K. Sugimoto, M. Henze, D.J. Lew, C. Wittenberg, and S.I. Reed. 1991. A cyclin B homolog in S. cerevisiae: Chronic activation of the Cdc28 protein kinase by cyclin prevents exit from mitosis. Cell 65: 163-174.

Girard, F., U. Strausfeld, A. Fernandez, and N.J.C. Lamb. 1991. Cyclin $A$ is required for the onset of DNA replication in mammalian fibroblasts. Cell 67: 1169-1179.

Glotzer, M., A.W. Murray, and M.W. Kirschner. 1991. Cyclin is degraded by the ubiquitin pathway. Nature 349: 132-138.

Gordon, C.B. and J.L. Campbell. 1991. A cell cycle-responsive transcriptional control element and a negative control element in the gene encoding DNA polymerase alpha in Saccharomyces cerevisiae. Proc. Natl. Acad. Sci. 88: 60586062 .

Hartwell, L.H. 1976. Sequential function of gene products relative to DNA synthesis in the yeast cell cycle. I. Mol. Biol. 104: 803-817.

1991. Twenty-five years of cell cycle genetics. Genetics 129: 975-980.

Hereford, L.M. and L.H. Hartwell. 1974. Sequential gene function in the initiation of Saccharomyces cerevisiae DNA synthesis. I. Mol. Biol. 84: 445-461.

Higgins, D.G. and P.A. Sharp. 1988. CLUSTAL: A package for performing multiple sequence alignment on a microcomputer. Gene 73: 237-244.

Holm, C., D.W. Meeks-Wagner, W.L. Fangman, and D. Botstein. 1986. A rapid, efficient method for isolating DNA from yeast. Gene 42: 169-173.

Jacobs, C.W., A.E. Adams, P.J. Szaniszlo, and J.R. Pringle. 1988. Functions of microtubules in the Saccharomyces cerevisiae cell cycle. I. Cell Biol. 107: 1409-1426.

Johnston, G.C. and R.A. Singer. 1983. Growth and the cell cycle of the yeast Saccharomyces cerevisiae I. Slowing S phase or nuclear division decreases the $\mathrm{G}_{1}$ cell cycle period. Exp. Cell Res. 149: 1-13.

Koff, A., F. Cross, A. Fisher, J. Schumacher, K. Leguellec, M. Philippe, and J.M. Roberts. 1991. Human cyclin E, a new cyclin that interacts with two members of the CDC2 gene family. Cell 66: 1217-1228. 
Labbe, J.C., M.G. Lee, P. Nurse, A. Picard, and M. Doree. 1988. Activation at $\mathrm{M}$-phase of a protein kinase encoded by a starfish homologue of the cell cycle control gene cdc2 ${ }^{+}$. Nature 335: 251-254.

Lahue, E.E., A.V. Smith, and T.L. Orr-Weaver. 1991. A novel cyclin gene from Drosophila complements $C L N$ function in yeast. Genes \& Dev. 5: 2166-2175.

Lew, D.J., V. Dulic, and S.I. Reed. 1991. Isolation of three novel human cyclins by rescue of $G_{1}$ cyclin $(C l n)$ function in yeast. Cell 66: 1197-1206.

Lew, D.J., N.J. Marini, and S.I. Reed. 1992. Different $G_{1}$ cyclins control the timing of cell cycle commitment in mother and daughter cells of the budding yeast $S$. cerevisiae. Cell 69: 317-327.

Lowndes, N.F., A.L. Johnson, and L.H. Johnston. 1991. Coordination of expression of DNA synthesis genes in budding yeast by a cell-cycle regulated trans factor. Nature 350: 247250.

Leopold, P. and P.H. O'Farrell. 1991. An evolutionarily conserved cyclin homolog from Drosophila rescues yeast deficient in $\mathrm{G}_{1}$ cyclins. Cell 66: 1207-1216.

Marini, N.J. and S.I. Reed. 1992. Direct induction of $\mathrm{G}_{1}$-specific transcripts following reactivation of the $\mathrm{Cdc} 28$ kinase in the absence of de novo protein synthesis. Genes \& Dev. 6: 557567.

Matsushime, H., M.F. Roussel, R.A. Ashmun, and C.J. Sherr. 1991. Colony-stimulating factor 1 regulates novel cyclins during the $G_{1}$ phase of the cell cycle. Cell 65: 701-713.

McIntosh, E.M., T. Atkinson, R.K. Storms, and M. Smith. 1991. Characterization of a short, cis-acting DNA sequence which conveys cell cycle stage-dependent transcription in Saccharomyces cerevisiae. Mol. Cell. Biol. 11: 329-337.

McKinney, J.D. and N. Heintz. 1991. Transcriptional regulation in the eukaryotic cell cycle. Trends Biochem. Sci. 16: 430435.

Mitchison, J.M. 1971. The biology of the cell cycle. Cambridge University Press, Cambridge, England.

Murray, A.W. and M.W. Kirschner. 1989. Dominoes and clocks: The union of two views of the cell cycle. Science 246: 614 621.

Nasmyth, K. 1985. A repetitive DNA sequence that confers cell-cycle START (CDC28)-dependent transcription on the HO gene in yeast. Cell 42: 225-235.

Nasmyth, K. and L. Dirick. 1991. The role of SWI4 and SWI6 in the activity of G1 cyclins in yeast. Cell 66: 995-1013.

Niwa, O. and M. Yanagida. 1988. Universal and essential role of MPF/cdc2 ${ }^{+}$(letter). Nature 336: 430.

Nurse, P. 1990. Universal control mechanism regulating onset of M-phase. Nature 344: 503-508.

O'Farrell, P. and P. Leopold. 1991. A consensus of cyclin sequences reveals homology with the ras oncogene. Cold Spring Harbor Symp. Quant. Biol. 56: 83-92.

Ogas, J., B.J. Andrews, and I. Herskowitz. 1991. Transcriptional activation of CLN1,CLN2, and a putative new $\mathrm{G}_{1}$ cyclin (HCS26) by SWI4, a positive regulator of $\mathrm{G}_{1}$-specific transcription. Cell 66: 1015-1026.

Osley, M.A. 1991. The regulation of histone synthesis in the cell cycle. Annu. Rev. Biochem. 60: 827-861

Pines, J. and T. Hunter. 1990a. p34cdc2: The $S$ and $M$ kinase. New Biol. 2: 389-401.

- 1990b. Human cyclin A is adenovirus ElA-associated protein p60 and behaves differently from cyclin B. Nature 346: $760-763$.

Pringle, J.R. and L.H. Hartwell. 1981. The Saccharomyces cerevisiae life cycle. In The molecular biology of the yeast Saccharomyces cerevisiae (ed. J. Strathern, E.W. Jones, and J.R.
Broach), pp. 97-142. Cold Spring Harbor Laboratory, Cold Spring Harbor, New York.

Richardson, H.E., C. Wittenberg, F. Cross, and S.I. Reed. 1989. An essential $G_{1}$ function for cyclin-like proteins in yeast. Cell 59: 1127-1133.

Sherman, F., G.R. Fink, and J.B. Hicks. 1989. Laboratory course manual for methods in yeast genetics. Cold Spring Harbor Laboratory, Cold Spring Harbor, New York.

Shuster, E.O. and B. Byers. 1989. Pachytene arrest and other meiotic effects of the start mutations in Saccharomyces cerevisiae. Genetics 123: 29-43.

Sikorski, R.S. and P. Hieter. 1989. A system of shuttle vectors and yeast host strains designed for efficient manipulation of DNA in Saccharomyces cerevisiae. Genetics 122: 19-27.

Singer, R.A. and G.C. Johnston. 1981. Nature of the $G_{1}$ phase of the yeast Saccharomyces cerevisiae. Proc. Natl. Acad. Sci. 78: 3030-3033.

Sun, H., D. Treco, N.P. Schultes, and J.W. Szostak. 1989. Double-strand breaks at an initiation site for meiotic gene conversion. Nature 338: 87-90.

Surana, U., H. Robitsch, C. Price, T. Schuster, I. Fitch, A.B. Futcher, and K. Nasmyth. 1991. The role of CDC28 and cyclins during mitosis in the budding yeast $S$. cerevisiae. Cell 65: 145-161.

Tsai, L.-H., E. Harlow, and M. Meyerson. 1991. Isolation of the human cdk2 gene that encodes the cyclin A- and adenovirus ElA-associated p33 kinase. Nature 353: 174-177.

Westendorf, J.M., K.I. Swenson, and J.V. Ruderman. 1989. The role of cyclin B in meiosis I. J. Cell Biol. 108: 1431-1444.

Wittenberg, C., K. Sugimoto, and S.I. Reed. 1990. G1-specific cyclins of $S$. cerevisiae: Cell cycle periodicity, regulation by mating pheromone, and association with the p34CDC28 protein kinase. Cell 62: 225-237.

Xiong, Y., T. Connolly, B. Futcher, and D. Beach. 1991. Human D-type cyclin. Cell 65: 691-699. 


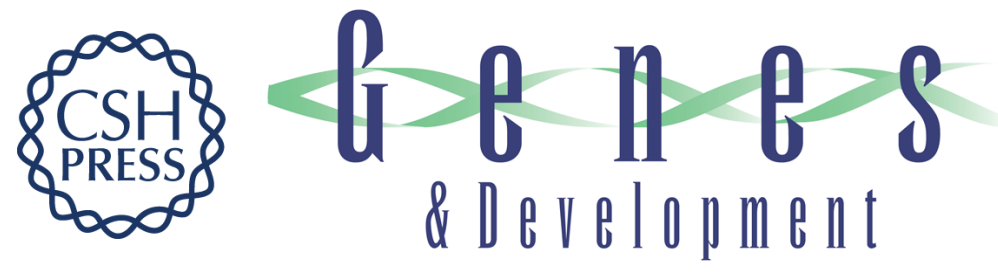

\section{CLB5: a novel B cyclin from budding yeast with a role in S phase.}

C B Epstein and F R Cross

Genes Dev. 1992, 6:

Access the most recent version at doi:10.1101/gad.6.9.1695 $\begin{array}{ll}\text { References } & \begin{array}{l}\text { This article cites } 53 \text { articles, } 17 \text { of which can be accessed free at: } \\ \text { http://genesdev.cshlp.org/content/6/9/1695.full.html\#ref-list-1 }\end{array}\end{array}$

License

Email Alerting

Receive free email alerts when new articles cite this article - sign up in the box at the top Service right corner of the article or click here.

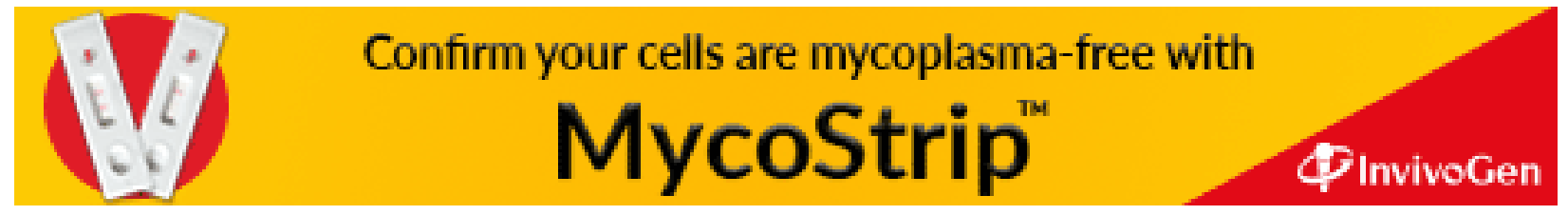

